Research Article

\title{
A case study to know the level of awareness about pharmacogenomics and its clinical application among doctors of Lucknow, Uttar Pradesh, India
}

\author{
Aditi Jhunjhunwala, Narendra Kumar*, Rahul Kumar, Sarvesh Singh, \\ Rakesh Kumar Dixit
}

Department of Pharmacology,

King George's Medical

University, Lucknow, Uttar

Pradesh, India

Received: 15 February 2016

Accepted: 21 March 2016

*Correspondence to:

Dr. Narendra Kumar,

Email: narenkgmu@gmail.com

\begin{abstract}
Background: Presently knowledge of pharmacogenomics is important for therapeutic purposes as well as for the prevention of many ADRs (adverse drug reactions). So this study was planned to know the level of awareness about pharmacogenomics and its clinical application among doctors of Lucknow, Uttar Pradesh, India.

Methods: The study was done through a survey among 400 doctors by a questionnaire method. The questions were formulated to know the awareness and extent of knowledge of doctor. The answers were in yes and no and the data collected was calculated in percentage.

Results: $79.75 \%$ doctors were well aware about pharmacogenomics. $13.0 \%$ doctors were not aware but wanted to know about it, while $7.25 \%$ of doctors were neither aware nor interested about pharmacogenomics.

Conclusions: Most of the doctors were aware about the pharmacogenomics theoretically and they need to be updated about its clinical application in their practice by seminars, presentation and workshops.
\end{abstract}

Copyright: (C) the author(s), publisher and licensee Medip Academy. This is an openaccess article distributed under the terms of the Creative Commons Attribution NonCommercial License, which permits unrestricted noncommercial use, distribution, and reproduction in any medium, provided the original work is properly cited.

Keywords: pharmacogenomics, Doctors, Awareness, Personalized medicine.

\section{INTRODUCTION}

Pharmacogenomics and pharmacogenetics are the two important words used commonly and interchangeably nowadays. Pharmacogenetics is dealing with the study of genetic makeup, SNPs (single nucleotide polymorphisms) and finding out their role in drug response. In pharmacogenomics the knowledge acquired by the pharmacogenetics is used for clinical application by giving suitable drug according to the genetic makeup as all the pharmacokinetic parameters like absorption, distribution, metabolism and excretion are dependent on it. $^{1,2}$

Genetic polymorphism in the drug metabolizing enzymes such as cytochrome P450s (CYP450s) have been shown to influence the fate and rate of drug metabolism. ${ }^{3}$ Pharmacogenomics helps in choosing right medicine for right person to avoid ADRs (adverse drug reactions) as well as treatment failure. This is an approach towards the personalized medicine, in which drugs and drug combinations are optimized for each individual's unique genetic makeup. ${ }^{1,4}$

On the basis of available literature, we can see variations in the drug response among individuals, which can lead difference in the efficacy of treatment as well as adverse drug reactions. ${ }^{5}$

Presently pharmacogenetics testing is available only to a small number of patients, but it will influence clinical practice to a larger extent in the near future. ${ }^{6}$ 


\section{METHODS}

The study was done through a survey among 400 doctors by a questionnaire method. The questions were formulated to know the awareness and extent of knowledge of doctor about pharmacogenomics. The answers were in yes and no and the data collected was calculated in percentage.

Table 1: Grading according to marks.

\begin{tabular}{|c|c|}
\hline Marks & Inference \\
\hline$>8$ & $\begin{array}{l}\text { Well aware about pharmacogenomics and its } \\
\text { clinical application }\end{array}$ \\
\hline $6-8$ & $\begin{array}{l}\text { Well aware about pharmacogenomics but } \\
\text { not its clinical application }\end{array}$ \\
\hline $3-5$ & $\begin{array}{l}\text { Not aware about pharmacogenomics but } \\
\text { willing to know }\end{array}$ \\
\hline$<3$ & Not aware about pharmacogenomics \\
\hline
\end{tabular}

\section{Statistical analysis}

All data were entered in MS excel for statistical analyses and data was summarized as percentage.

\section{RESULTS}

A total number of 400 doctors were given a questionnaire about pharmacogenomics. Among them, 314 were physicians and 86 were surgeons. In terms of educational qualification 207 were medical graduates, 152 were post graduates and 41 were super specialists (Table 2).

Table 2: Doctors and their qualifications.

\begin{tabular}{|c|c|c|c|c|}
\hline \multicolumn{2}{|c|}{ Graduates } & $\begin{array}{l}\text { Post } \\
\text { graduates }\end{array}$ & $\begin{array}{l}\text { Super } \\
\text { specialists }\end{array}$ & Total \\
\hline Physicians & 207 & 89 & 18 & 314 \\
\hline Surgeons & 0 & 63 & 23 & 86 \\
\hline Total & 207 & 152 & 41 & 400 \\
\hline
\end{tabular}

Table 3: Extent of awareness among doctors.

\begin{tabular}{|ll|}
\hline $\begin{array}{l}\text { Extent of awareness } \\
\text { Doctors aware about pharmacogenomics as } \\
\text { well as its clinical application }\end{array}$ & $35.25 \%$ \\
\hline $\begin{array}{l}\text { Doctors aware about pharmacogenomics but } \\
\text { not its clinical application }\end{array}$ & $44.5 \%$ \\
\hline $\begin{array}{l}\text { Doctors not aware about pharmacogenomics } \\
\text { but willing to know }\end{array}$ & $13.0 \%$ \\
\hline $\begin{array}{l}\text { Doctors having no interest in } \\
\text { pharmacogenomics }\end{array}$ & $7.25 \%$ \\
\hline
\end{tabular}

In our study, $79.75 \%$ (319) of the doctors were aware about pharmacogenomics and even $35.25 \%$ (141) doctors were well versed with its clinical application. $20.25 \%$ (81) doctors were not aware about pharmacogenomics but $13 \%$ (52) showed interest to know more about it.
$7.25 \%$ (29) doctors were not at all interested in pharmacogenomics (Table 3).

\section{DISCUSSION}

Many doctors showed interest in new emerging possibilities like personalized medicine and pharmacogenomics. An earlier study on faculty members about their knowledge of pharmacogenetics, found them as $6.3 \%$ excellent, $9.4 \%$ very good, $28.1 \%$ good, $37.5 \%$ fair and $18.8 \%$ as poor, while in our study, $79.75 \%$ of the doctors were aware and only $7.25 \%$ doctors showed no interest in pharmacogenomics. ${ }^{7}$

There are lots of knowledge barriers due to which health professionals are not confident in using pharmacogenomics as a tool for their drug therapy decision-making even though they are well aware theoretically about it. ${ }^{8,9,10}$ Keeping in mind the interest of healthcare professionals towards new emerging field of pharmacogenomics, more presentation and seminars should be held to spread awareness and simultaneously practical workshops can give confidence to apply this science in their routine practice.

\section{ACKNOWLEDGEMENT}

Author thankful to research cell, King George's Medical University, Lucknow, Uttar Pradesh, India for supporting this project.

Funding: By Research Cell, King George's Medical University, Lucknow, Uttar Pradesh, India, (Institutional intramural funding)

Conflict of interest: None declared

Ethical approval: The study was approved by the Institutional Ethics Committee (71st ECM IIB IMR/P15)

\section{REFERENCES}

1. Relling MV, Giacomini KM. Pharmacogenetics. In: Brunton LL, Chabner BA, Knollmann BC, editors. Goodman and Gilman's the pharmacological basis of therapeutics. $12^{\text {th }}$ edi. New York: McGraw-Hill; 2011:145-68.

2. Johnson JA. Pharmacogenetics: potential for individualized drug therapy through genetics. Trends Genet. 2003;19(11):660-6.

3. Cordero P, Ashley EA. Whole-genome sequencing in personalized therapeutics. Clinical Pharmacology and Therapeutics. 2012;91:1001-9.

4. Squassina A, Manchia M, Manolopoulos VG, Artac M, Lappa-Manakou C, Karkabouna S, et al. Realities and expectations of pharmacogenomics and personalized medicine: impact of translating genetic knowledge into clinical practice. Pharmacogenomics. 2010;11(8):1149-67.

5. Kudzi W, Adjei GO, Ofori-Adjei D, Dodoo AN. Pharmacogenetics in Ghana: reviewing the evidence. Ghana Med J. 2011;45(2):73-80. 
6. Lesko LJ. Personalized medicine: elusive dream or imminent reality? Clin Pharmacol Ther. 2007;81(6):807-16.

7. Kudzi W, Addy BS, Dzudzor B. Knowledge of pharmacogenetics among healthcare professionals and faculty members of health training institutions in Ghana. Ghana Medical Journal. 2015;49(1):50-6.

8. Lesko LJ, Johnson JA. Academia at the crossroads: education and training in pharmacogenomics. Pers Med. 2012;9:497-506.
9. Stanek EJ, Sanders CL, Taber KA, Khalid M, Patel A, Verbrugge RR, et al. Adoption of pharmacogenomic testing by US physicians: results of a nationwide survey. Clin Pharmacol Ther. 2012;91(3):450-8.

10. Haga SB, Burke W, Ginsburg GS, Mills R, Agans R. Primary care physicians knowledge of and experience with pharmacogenetic testing. Clin Genet. 2012;82(4):3883-94.

Cite this article as: Jhunjhunwala A, Kumar N, Kumar R, Singh S, Dixit RK. A case study to know the level of awareness about pharmacogenomics and its clinical application among doctors of Lucknow, Uttar Pradesh, India. Int J Basic Clin Pharmacol 2016;5:739-41. 